\title{
Patriline-level variability in olfactory learning in the honey bee*
}

\author{
David LALOI ${ }^{1}$, Minh-Hà PHAM-DELEGUE ${ }^{2}$
}

\begin{abstract}
${ }^{1}$ UPMC Univ Paris 06 - École Normale Supérieure - AgroParisTech - CNRS, UMR 7625, Laboratoire Écologie \& Évolution, 7 quai Saint Bernard, case 237, 75005 Paris Cedex 05, France

${ }^{2}$ ParisTech - Paris Institute of Technology, 28 rue des Saints-Pères, 75343 Paris Cedex 07, France
\end{abstract}

Received 20 March 2009 - Revised 30 July 2009 - Accepted 25 August 2009

\begin{abstract}
Genetically determined differences among honeybee workers are known to contribute to task specialisation. To investigate the genetic component of olfactory learning we used proboscis extension conditioning to record individual performance, and a patriline-level analysis to separate the variance in learning performance into its different components. We found that the among-patriline within-colony component (solely genetic) explained $11.2 \%$ of the variance in acquisition performance and $6.5 \%$ of the variance in resistance to extinction. While environmental effects appeared to be the main source of variation, our results confirm that olfactory learning has a significant genetic basis. If colonies benefit from genetic differences among workers in task expression thresholds, colonies might also benefit from genetic differences in cognitive performance among workers by influencing task performance.
\end{abstract}

olfactory learning / genetic determinism / patrilines / heritability / honeybee

\section{INTRODUCTION}

A number of empirical studies have indicated that the honeybee colony can benefit from genetic differences among workers, supporting the hypothesis that genetic diversity due to polyandry may be a determining factor in task specialisation and therefore the ability of colonies to adapt to the environment (Calderone and Page, 1988; Robinson, 1992, 2002). For instance, genetically diverse colonies exhibit higher productivity and greater foraging effort than genetically uniform colonies (Mattila and Seeley, 2007), which is linked to increased foragingrelated communication (Mattila et al., 2008). According to the threshold model of division of labour (Robinson and Page, 1989; Beshers and Fewell, 2001), the benefits of genetic di-

Corresponding author: D. Laloi, david.laloi@upmc.fr

* Manuscript editor: Monique Gauthier versity come from genetically determined differences in response thresholds of workers, as suggested for foraging behaviour (Cox and Myerscough, 2003), thermoregulation (Jones et al., 2004) and defense (Lenoir et al., 2006). In a study of a strain artificially selected for pollen-storing, Page et al. (1998) showed interesting relationships between the genotype of workers, their responses to water and sucrose, and their foraging behaviour, suggesting that varying response thresholds can lead to a division of labour.

Learning and memory are involved in many tasks performed by worker bees (Menzel and Müller, 1996; Giurfa, 2007). The impressive cognitive performances of bees (e.g. Giurfa et al., 2001) may enhance both foraging and task performance within the colony. This idea is supported by results from inter-colony comparisons, such as the correlation between learning performances and foraging success in bumble bees (Raine and Chittka, 2008). As for other tasks, genetically determined differences 
in individual learning performance may contribute to the ability of a colony to adapt to the environment.

The importance of variability in learning performances of honeybees has been shown since pioneer studies from the mid-twentieth century (e.g. Free, 1958). It is widely recognized that olfactory learning in particular, shows high inter-individual variability. While this has motivated many studies on the factors that can account for this variability (e.g. Bhagavan et al., 1994; Laloi et al., 2001; Arenas and Farina, 2008), few have addressed the role of genotype quantitatively. Estimates of the genetic component of olfactory learning were first calculated using the Cape bees Apis mellifera capensis (Brandes, 1988), as were estimates of heritability of morphological characters (Moritz and Klepsch, 1985). In Cape bees, laying workers are able to produce female offspring by parthenogenesis (Anderson, 1963), which provides the opportunity to estimate heritability by motheroffspring regression. Brandes and colleagues gave estimates of the heritability of learning and also selected lines for good and poor learning performances (Brandes, 1988; Brandes and Menzel, 1990; Brandes, 1991). In honeybees other than Cape bees, Bhagavan et al. (1994) selected on the haploid paternal genotype by measuring learning performances of drones and producing lines of high- and low-learning performances. The responses of workers from selected lines differed as early as the $F_{1}$ generation. These authors concluded that genotype, but not age and caste, account for a substantial portion of the within-colony variability in olfactory learning performance, but they did not give an actual estimate of the genetic component of inter-individual variability.

In the present study, our goal was to assess the genetic component of the variation in olfactory learning, focussing on the amongpatriline within-colony variation. We recorded learning performance by conditioning the proboscis extension response, a procedure widely used in studies on olfactory learning in the honeybee including those investigating genetics of learning (Bitterman et al., 1983; Brandes, 1988, 1991; Bhagavan et al., 1994;
Menzel and Müller, 1996). Here, we examined two types of responses: acquisition during the conditioning phase, and resistance of the conditioned response to extinction. Subsequently, we applied a patriline-level analysis to separate the variance in learning performance into different components. Analysis of variance, a relevant way to estimate heritability (Lynch and Walsh, 1998), had not been used to analyze learning performances of honeybees. Yet it can be applied to haplodiploid organisms (Liu and Smith, 2000) and was successfully used to estimate heritability of morphological and physiological traits in Hymenoptera (Bargum et al., 2004; Fjerdingstad, 2005). Moreover, it does not require selective breeding and can be used to estimate the genetic component of variability from bees collected from natural colonies.

\section{MATERIALS AND METHODS}

\subsection{Animals}

Experiments were conducted on worker honeybees, Apis mellifera, reared under standard laboratory conditions (e.g. Sandoz et al., 2000) to control for confounding factors that could affect the olfactory learning performance such as age (Laloi et al., 2001), previous olfactory experience (Sandoz et al., 2000) or rearing environment (Arenas and Farina, 2008). Newly emerged bees were collected from combs of capped brood obtained from indoor hives, and were caged in groups of about 60 individuals of the same age. Caged bees were maintained in an incubator $\left(32-34{ }^{\circ} \mathrm{C}, 55 \%\right.$ relative humidity, in darkness) and were fed with sugar and water ad libitum, and with pollen as a source of protein until 8-days of age. They were tested when they were 14-15 days old.

\subsection{Assessment of learning performance}

The proboscis extension response can be trained using a Pavlovian conditioning procedure by presenting an odour in temporal association with a sugar reward. The experimental procedure has been used in many studies on olfactory learning of honeybees, and allows for good control of the conditioning parameters and physiological variables 
(Takeda, 1961; Bitterman et al., 1983; Menzel et al., 1993; Sandoz et al., 2000). Bees were restrained individually in glass holders leaving their antennae and mouthparts free, and were starved for 3-4 h. This starvation duration is within the range usually applied (Giurfa, 2007) and it ensured appropriate appetitive motivation in our experimental conditions. The stimulation device created a constant airflow, either scented or unscented, delivered to the bees through a $1-\mathrm{cm}$-diameter glass tube. This flow consisted of a main vector unscented airflow $(50 \mathrm{~mL} / \mathrm{s})$ and a secondary one $(2.5 \mathrm{~mL} / \mathrm{s})$ used for odour stimulation. The odour source was a piece of filter paper, $40 \times 3 \mathrm{~mm}$, soaked with $10 \mu \mathrm{L}$ of pure odorant (linalool 95-97\%, Sigma) and inserted in a disposable Pasteur pipette. The experimenter injected the secondary flow into the main airflow, either through the pipette containing the odour source or an identical empty pipette. A fan placed opposite the delivery tube extracted the released odours from the experimental room.

Before every trial, bees were positioned for $30 \mathrm{~s}$ in the airflow to familiarize them with the mechanical stimulation. Bees were then subjected to 3 conditioning trials (acquisition phase) followed by 5 test trials (extinction phase) with 15 -min intertrial intervals. During conditioning trials, bees were stimulated with the odour stimulus for $6 \mathrm{~s}$, and rewarded with a drop of a $30 \% \mathrm{w} / \mathrm{w}$ sucrose solution for the last $3 \mathrm{~s}$. Test trials consisted of a 6-s presentation of the odour stimulus alone. Bees that failed to respond to any sugar presentation were discarded from the experiment, as this may have been due to a lack of appetitive motivation or injury caused by the holding set-up (Brandes, 1988). Bees showing spontaneous responses at the first presentation of the odour were also discarded since later responses of such individuals could not be interpreted as purely associative (Sandoz et al., 2000). Conditioning scores were measured as the number of conditioned responses during the acquisition phase (ranging from 0 to 2). Extinction scores were measured as the number of responses during the extinction phase (ranging from 0 to 5). Similar scoring systems based on sum of responses were used to estimate learning performance (Brandes, 1988; Bhagavan et al., 1994; Scheiner et al., 2001).

\subsection{Determination of patrilines}

Patrilines were determined by analysis of nuclear DNA microsatellite markers. Among the numerous microsatellites available (Solignac et al.,
2003), five loci provided sufficient genetic variability to classify workers into distinct patrilines within the studied colonies (A14, A29, A76, A107 and B124; Estoup et al., 1994). The methods used for extraction, PCR amplification and determination of alleles are detailed in Lenoir et al. (2006). Patrilines are easily identified due to haplodiploid determination of sex (Estoup et al., 1994). Using the genotypes of all the workers, it is possible to infer the maternal alleles (either two alleles in equal proportions among workers when the queen is heterozygous at the considered locus, or the same allele in all the workers when the queen is homozygous at the considered locus). Paternal haplotypes are then deduced by subtraction.

\subsection{Statistical analyses}

Variances were estimated separately for conditioning and extinction scores following a nested analysis of variance (Lynch and Walsh, 1998) with three hierarchical levels: the total variance in each score was partitioned into a between-colony component, a between-patriline within-colony component and a between-worker within-patriline component. Patrilines within a colony were assumed to experience the same average environment, while workers within patrilines might have had different individual environmental experiences (for instance during their development) and might differ by their maternal haplotype. Accordingly, the betweenpatriline within-colony component ("patriline component") contains variance arising only from genetic (additive + dominance) effects, assuming epistatic effects to be negligible. In a haplodiploid system, this patriline component amounts to half the genetic variance. Hence, broad sense heritabilities can be estimated as $h^{2}=V_{\text {Genetic }} / V_{\text {Phenotypic }}=$ $2 \sigma_{\text {patriline }} / \sigma_{\text {total }}$. This follows the method applied to measure genetic component of morphological traits in haplodiploid species (Fjerdingstad, 2005).

\section{RESULTS}

Patriline-level analysis of olfactory learning was conducted on workers from two hives (76 and 172 workers). We detected six and eight patrilines respectively, which is within range among colonies produced by naturally mated queens (Tarpy and Nielsen, 2002). In addition, we measured performances among workers from four other colonies $(127,149,181$ 
Table I. Proportion of variance in olfactory learning performances explained by different levels of analysis and corresponding heritability estimates for both the conditioning score (acquisition performance) and the extinction score (resistance to extinction).

\begin{tabular}{llcc}
\hline & & \% variance explained & broad sense $\mathrm{h}^{2}$ \\
\hline \multirow{3}{*}{ Conditioning } & between colonies $(\mathrm{n}=2)^{*}$ & 0.4 & \\
score & between patrilines within colonies & 11.2 & 0.22 \\
& between workers within patrilines & 88.4 & \\
& between colonies $(\mathrm{n}=6)^{* *}$ & 8.5 & \multirow{2}{*}{0.13} \\
\multirow{2}{*}{ Extinction } & between colonies $(\mathrm{n}=2)^{*}$ & 1.3 & \\
score & between patrilines within colonies & 6.5 & \\
& between workers within patrilines & 92.2 & \\
& between colonies $(\mathrm{n}=6)^{* *}$ & 15.6 & \\
\hline
\end{tabular}

* Colonies in which patriline-level analysis was conducted.

** Larger set including four colonies in which individual learning performances were measured but patrilines were not characterized (and thus patriline-level analysis was not conducted).

and 198 workers) in which patrilines were not characterized. This was done to refine the estimates of between-colony variation.

Table I shows the proportion of variance in olfactory learning performances explained at different levels. In general, the amount of variance explained at each level appeared similar for conditioning and extinction scores: the greatest part of the variance was explained by differences among workers within patrilines (88.4\% and $92.2 \%$ for conditioning and extinction scores, respectively) while the patriline component explained $11.2 \%$ and $6.5 \%$ of the total variance, leading to $\mathrm{h}^{2}$ estimates of 0.22 for the conditioning score and 0.13 for the extinction score.

The between-colony component was very small (Tab. I) but would have been underestimated if it had been based solely on the two colonies in which patrilines were characterized. A larger set of colonies led to a larger estimate of the between-colony component: $8.5 \%$ and $15.6 \%$ for the conditioning and extinction scores, respectively. Differences between colonies can be due to genetic effects (genetic differences between the queens and between the pools of fathers taken as a whole) and to environmental effects. Underestimation of this between-colony component may thus affect the estimate of the between-worker within-patriline component (influenced by both queen genotype and environment) but it should not affect the mea- sure of the patriline component (only due to genetic differences among fathers within colonies). Hence, it is unlikely to affect the $\mathrm{h}^{2}$ estimates based on a patriline-level analysis. Finally, even when this underestimation is accounted for, the between-worker withinpatriline component remains the major source of variance, larger than the variance between patrilines.

\section{DISCUSSION}

Using an ANOVA approach, we estimated the genetic and environmental components of the individual variability in olfactory learning performances in the honeybee using conditioning of the proboscis extension response. We found a similar partition of variance for both acquisition and resistance to extinction: environmental factors appeared to be the main source of variation, nevertheless the betweenpatriline within-colony component (genetic influence due to paternal haplotype) explained $11.2 \%$ of the variance of the acquisition performance (responses during a conditioning process) and $6.5 \%$ of the variance in resistance to extinction (responses during an extinction procedure).

Our estimates of heritabilities ( 0.22 and 0.13 according to the considered score) are lower than those found in previous studies. By selecting directly on parthenogenetic workers 
of Cape bees, Brandes (1988) found $h^{2}$ values ranging between 0.39 and 0.54 depending on the method used. Bhagavan et al. (1994) did not provide an estimate of heritability but they showed that selection on haploid drone genotype rapidly generated lines of high- and low-learning performances, indicating a major effect of genotype on the within-colony variability. Many factors can affect the estimation of heritability, including differences in the studied populations, in environment and in methodology; it is thus quite difficult to explain differences in $\mathrm{h}^{2}$ estimates. While slightly lower than the previously published values, our estimates still indicate that olfactory learning has a significant genetic component.

The process by which genetic variation for learning and memory abilities is maintained has often raised questions. It is usually acknowledged that there are trade-offs between learning abilities and other fitness components (McGuire and Hirsch, 1977; Rose, 1982) and that selection on these abilities will depend on a typical cost-benefit balance (Niven et al., 2003; Mery and Kawecki, 2005). The costs of learning have been demonstrated empirically, in Drosophila for instance (Mery and Kawecki, 2003, 2005). In social insects exhibiting task partitioning, an alternative explanation for a high genetic variation in learning comes from possible benefits to colony fitness. Intra-colonial genetic diversity has been shown to increase various performances of honeybee colonies such as resistance to disease (Tarpy and Seeley, 2006; Seeley and Tarpy, 2007), thermoregulation (Jones et al., 2004), workforce productivity and foraging effort (Mattila and Seeley, 2007). In agreement with the threshold model of division of labour (Beshers and Fewell, 2001), it is usually supposed that the better performances of genetically diverse colonies are due to genetically determined differences among workers of different patrilines in response thresholds for task expression (Robinson and Page, 1989; Beshers and Fewell, 2001; Cox and Myerscough, 2003). Indeed, several tasks such as waggle dancing (Arnold et al., 2002), food scouting (Dreller, 1998) or defence (Lenoir et al., 2006) are not performed evenly among patrilines in colonies. Mattila et al. (2008) gave evidence of one potential mechanism that can link differences in individual behaviour and colony performance: workers from genetically diverse colonies produce more waggle dancing, and this enhanced communication leads to greater foraging rates relative to genetically uniform colonies. Variation in learning performance, as found in our study, could be one another mechanism linking differences in individual behaviour and colony performance. At the colony level, inter-individual variation in learning may contribute to task specialisation of workers and, therefore, to the ability of a colony to adapt to the environment (Robinson, 1992). This variation can be achieved by maintaining a large individual component (among individuals within patrilines) that is highly influenced by environmental factors such as during development. Nevertheless, in accordance with previous work on the heritability of olfactory learning (Brandes and Menzel, 1990; Brandes, 1991), our results indicate that a genetic component also contributes to this variation.

An impressive number of studies have emphasized the role of learning and memory in a quite diverse range of experience-dependent behaviours in honeybees (for a review, see Giurfa, 2007). In the same way the threshold model (stricto sensu) assumes that the performances of colonies benefit from genetically determined differences among workers in response thresholds for task expression (Robinson and Page, 1989; Beshers and Fewell, 2001), colonies might also benefit from genetically determined differences in cognitive performance. Moreover, our results suggest that an optimal balance should exist between environmental and genetic determinism of individual variation, which could enable bees to adjust their learning performances in response to environmental variations based on genetically determined response patterns. Even though the genetic component appears weak compared to the environmental component, patriline accounts for a significant part of the within-colony variation of learning, thus exerting selective pressure on queens to achieve optimal genetic 
diversity either through the number or the quality of mates.

\section{ACKNOWLEDGEMENTS}

Michel Solignac and Dominique Vautrin (Population, Génétique et Evolution, CNRS Gif-surYvette, France) provided lab facilities and assistance in DNA analysis. Bernard Roger, Mercedes Charreton and Jean-François Odoux helped in rearing the bees. Joël White and two anonymous referees gave valuable comments on the manuscript. This study was carried out in the former Laboratoire de Neurobiologie Comparée des Invertébrés, INRA, in Bures-sur-Yvette (France).

Variabilité de l'apprentissage olfactif chez l'abeille au niveau des lignées paternelles.

apprentissage olfactif / déterminisme génétique / lignées paternelles / héritabilité / abeille

Zusammenfassung - Individuelle Variabilität des Duftlernens bei der Honigbiene: Abschätzung der genetischen Komponente unter Verwendung einer Patrilinienanalyse. Genetisch bestimmte Unterschiede zwischen Arbeiterinnen der Honigbiene tragen zur Aufgabenteilung und somit zur Anpassung des Volkes an die Umwelt bei. In der vorliegenden Studie untersuchten wir, ob sich genetisch unterschiedliche Arbeiterinnen (Arbeiterinnen verschiedener Patrilinien) in ihrem Duftlernverhalten unterscheiden. Wir untersuchten dies mit Hilfe des Rüsselreflexes, um individuelle VerhaltensäuBerungen aufzuzeichnen. Hierbei untersuchten wir zwei verschiedene Verhaltenstypen: Akquisition während der Konditionierungsphase und resistance to extinction der konditionierten Reaktion während einer Extinktionsphase. Anschließend führten wir Patrilinienanalysen durch, um die verschiedenen Komponenten der Varianzen des Lernverhaltens aufzuschlüsseln: Varianzen zwischen verschiedenen Völkern, zwischen verschiedenen Patrilinien innerhalb eines Volkes und zwischen Arbeiterinnen innerhalb einer Patrilinie. Wir fanden, dass 11,2 \% der Varianz der Akquisition und 6,5\% der Varianz der resistance to extinction durch Unterschiede zwischen verschiedenen Patrilinien innerhalb eines Volkes erklärt werden können. Die Erblichkeiten liegen bei 0,22 , bzw. 0,13 . Umwelteinflüsse scheinen die Hauptquelle der Varianzen zu sein. Doch unsere Ergebnisse bestätigen, dass auch das olfaktorische Lernen eine signifikante genetische Grundlage hat. Gleichermaßen nimmt das Schwellenmodell an, daß Völker von genetischen Unterschieden zwischen den Arbeiterinnen profitieren, die ihre Schwellen bestimmen, bestimmte Aufgaben im Volk zu übernehmen. Die Völker könnten ebenso von genetischen Unterschieden in den kognitiven Leistungen zwischen Arbeiterinnen profitieren: durch den Einfluss von Lernen und Gedächtnis auf die Aufgabenwahrnehmung.

Olfaktorisches Lernen / Genetischer Determinismus / Patrilinien / Erblichkeit / Honigbiene

\section{REFERENCES}

Anderson R.H. (1963) The laying worker in Cape honeybee, Apis mellifera capensis, J. Apicult. Res. 2, 85-92.

Arenas A., Farina W.M. (2008) Age and rearing environment interact in the retention of early olfactory memories in honeybees, J. Comp. Physiol. A 194, 629-640.

Arnold G., Quenet B., Papin C., Masson C., Kirchner W.M. (2002) Intra-colonial variability in the dance communication in honeybees (Apis mellifera), Ethology 108, 751-761.

Bargum K., Boomsma J.J., Sundström L. (2004) A genetic component to size in queens of the ant, Formica truncorum, Behav. Ecol. Sociobiol. 57, 9-16.

Beshers S.N., Fewell J.H. (2001) Models of division of labor in insect societies, Annu. Rev. Entomol. 46, 413-430.

Bhagavan S., Benatar S., Cobey S., Smith B.H. (1994) Effect of genotype but not of age or caste on olfactory learning performance in the honey bee, Apis mellifera, Anim. Behav. 48, 1357-1369.

Bitterman M.E., Menzel R., Fietz A., Schäfer S. (1983) Classical conditioning of proboscis extension in honeybees (Apis mellifera), J. Comp. Psychol. 97, 107-119.

Brandes C. (1988) Estimation of heritability of learning behavior in honeybees (Apis mellifera capensis), Behav. Genet. 18, 119-132.

Brandes C. (1991) Genetic differences in learning behavior in honeybees (Apis mellifera capensis), Behav. Genet. 21, 271-294.

Brandes C., Menzel R. (1990) Common mechanisms in proboscis extension conditioning and visual learning revealed by genetic selection in honeybees (Apis mellifera capensis), J. Comp. Physiol. A $166,545-552$.

Calderone N.W., Page R.E. Jr. (1988) Genotypic variability in age polymorphism and task specialization in the honey bee, Apis mellifera (Hymenoptera: Apidae), Behav. Ecol. Sociobiol. 22, 17-25.

Cox M.D., Myerscough M.R. (2003) A flexible model of foraging by a honey bee colony: the effect of individual behaviour on foraging success, J. Theor. Biol. 223, 179-197. 
Dreller C. (1998) Division of labor between scouts and recruits: genetic influence and mechanisms, Behav. Ecol. Sociobiol. 43, 191-196.

Estoup A., Solignac M., Cornuet J.M. (1994) Precise assessment of the number of patrilines and of genetic relatedness in honeybee colonies, Proc. R. Soc. London B 258, 1-7.

Fjerdingstad E.J. (2005) Control of body size of Lasius niger ant sexuals - worker interests, genes and environment, Mol. Ecol. 14, 3123-3132.

Free J.B. (1958) The ability of worker honeybees (Apis mellifera) to learn a change in the location of their hives, Anim. Behav. 6, 219-223.

Giurfa M. (2007) Behavioral and neural analysis of associative learning in the honeybee: a taste from the magic well, J. Comp. Physiol. A 193, 801-824.

Giurfa M., Zhang S., Jenett A., Menzel R., Srinivasan M.V. (2001) The concepts of 'sameness' and 'difference' in an insect, Nature 410, 930-933.

Jones J.C., Myerscough M.R., Graham S., Oldroyd B.P. (2004) Honey bee nest thermoregulation: diversity promotes stability, Science 305, 402-404.

Laloi D., Gallois M., Roger B., Pham-Delègue M.H. (2001) Changes with age in the olfactory conditioning performance of worker honey bees (Apis mellifera L.), Apidologie 32, 231-242.

Lenoir J.C., Laloi D., Dechaume-Moncharmont F.X., Solignac M., Pham M.H. (2006) Intra-colonial variation of the sting extension response in the honey bee Apis mellifera, Insect. Soc. 53, 80-85.

Liu F.H., Smith S.M. (2000) Estimating quantitative genetic parameters in haplodiploid organisms, Heredity 85, 373-382.

Lynch M., Walsh B. (1998) Genetics and analysis of quantitative traits, Sinauer Associates, Sunderland.

Mattila H.R., Seeley T.D. (2007) Genetic diversity in honey bee colonies enhances productivity and fitness, Science 317, 362-364.

Mattila H.R., Burke K.M., Seeley T.D. (2008) Genetic diversity within honeybee colonies increases signal production by waggle-dancing foragers, Proc. R. Soc. London B 275, 809-816.

McGuire T.R., Hirsch J. (1977) Behavior-genetic analysis of Phormia regina: conditioning, reliable individual-differences, and selection, Proc. Natl Acad. Sci. (USA) 74, 5193-5197.

Menzel R., Müller U. (1996) Learning and memory in honeybees: from behavior to neural substrates, Annu. Rev. Neurosci. 19, 379-404.

Menzel R., Greggers U., Hammer M. (1993) Functionnal organization of appetitive learning and memory in a generalist pollinator, the honey bee, in: Papaj D.R., Lewis A.C. (Eds.), Insect learning, Chapman and Hall, New-York, pp. 79-125.

Mery F., Kawecki T.J. (2003) A fitness cost of learning ability in Drosophila melanogaster, Proc. R. Soc. London B 270, 2465-2469.
Mery F., Kawecki T.J. (2005) A cost of long-term memory in Drosophila, Science 308, 1148.

Moritz R.F.A., Klepsch A. (1985) Estimating heritabilities of worker characters: a new approach using laying workers of the cape honeybee (Apis mellifera capensis Esch.), Apidologie 16, 47-56.

Niven J.E., Vähäsöyrinki M., Juusola M. (2003) Shaker $\mathrm{K}^{+}$-channels are predicted to reduce the metabolic cost of neural information in Drosophila photoreceptors, Proc. R. Soc. London B (Suppl.) 270, S58-S61.

Page R.E. Jr., Erber J., Fondrk M.K. (1998) The effect of genotype on response thresholds to sucrose and foraging behavior of honey bees (Apis mellifera L.), J. Comp. Physiol. A 182, 489-500.

Raine N.E., Chittka L. (2008) The correlation of learning speed and natural foraging success in bumblebees, Proc. R. Soc. London B 275, 803-808.

Robinson G.E. (1992) Regulation of division of labor in insect societies, Annu. Rev. Entomol. 37, 637665.

Robinson G.E. (2002) Genomics and integrative analyses of division of labor in honeybee colonie, Am. Nat. 160, S161-S172.

Robinson G.E., Page R.E. Jr. (1989) Genetic basis for division of labor in an insect society, in: Breed M.D., Page R.E. Jr. (Eds.), The genetics of social evolution, Westview Press, Boulder, pp. 61-80.

Rose M.R. (1982) Antagonistic pleiotropy, dominance, and genetic variation, Heredity 48, 63-78.

Sandoz J.C., Laloi D., Odoux J.F., Pham-Delègue M.H. (2000) Olfactory informaton transfer in the honeybee: compared efficiency of classical conditioning and early exposure, Anim. Behav. 59, 1025-1034.

Scheiner R., Page R.E. Jr., Erber J. (2001) The effects of genotype, foraging role, and sucrose responsiveness on the tactile learning performance of honey bees (Apis mellifera L.), Neurobiol. Learn. Mem. 76, 138-150.

Seeley T.D., Tarpy D.R. (2007) Queen promiscuity lowers disease within honeybee colonies, Proc. R. Soc. London B 274, 67-72.

Solignac M., Vautrin D., Loiseau A., Mougel F., Baudry E., Estoup A., Garnery L., Haberl M., Cornuet J.M. (2003) Five hundred and fifty microsatellite markers for the study of the honeybee (Apis mellifera) genome, Mol. Ecol. Notes 3, 307311.

Takeda K. (1961) Classical conditioned response in the honey bee, J. Insect Physiol. 6, 168-179.

Tarpy D.R., Nielsen D.I. (2002) Sampling error, effective paternity, and estimating the genetic structure of honey bee colonies (Hymenoptera: Apidae), Ann. Entomol. Soc. Am. 95, 513-528.

Tarpy D.R., Seeley T.D. (2006) Lower disease infections I nhoneybee (Apis mellifera) colonies headed by polyandrous vs. monandrous queens, Naturwissenschaften 93, 195-199. 